Ann. Biol. anim. Bioch. Biophys., 1979, 19 (2 A), 375-383.

\title{
Return of postpartum menstruation and fertility in laboratory Macaca fascicularis
}

\author{
by D. C. DANG
}

Laboratoire d'Anatomie, UER Biomédicale, 45 rue des Saints-Pères, 75270 Paris. Laboratoire de Physiologie de la Reproduction, Université Paris VI, 78350 Jouy-en-josas, France.

Summary. Return of menstruation and fertility after parturition was studied in 28 healthy Macaca fascicularis females raised in the laboratory. Three cases were defined :

1) Non-nursing females (table 1) : The menstrual cycle reappeared after a mean of $61.7 \pm$ 7.3 days and its duration was immediately normal. Fertility, which was zero before menstruation reappeared, became normal after two cycles.

2) Nursing females which menstruated during lactation (table 2) : Fifteen out of 21 nursing females menstruated during the nursing period at a mean of $50.9 \pm 8.3$ days after parturition. Menstruation was followed by a return of the normal cycles only after weaning. During nursing, mothers with young clinging to the abdomen refused to copulate. Fertility, low before menstruation reappaered after weaning, was immediately reestablished during the following cycles.

3) Females which presented amenorrhea during lactation (table 4) : Regular menstrual cycles began at a mean of $50.5+20.8$ days after weaning. Fertility, at zero before menstruation reappaered, was reestablished more slowly than in the females of the preceding group.

While fertility became immediately normal after cesarian during the first half of gestation, even before menstruation reappeared, it only returned to normal gradually after parturition, but faster when the mother did not nurse. In our rearing conditions, the season did not influence postpartum reestablishment of the reproductive function of Macaca fascicularis females. The pattern of fertility in these primates thus resembled that of women.

\section{Introduction.}

Most mammals possess mechanisms which reduce fertility during lactation. The ovarian function is reestablished immediately at parturition but implantation may be delayed, or there is a pause in ovarian activity during all or part of the nursing period. In order to study the mechanisms governing the pause of the ovarian function during nursing, we must first determine the exact time-course of this pause in relation to the duration of the nursing period. The anestrus in seasonally anestrous animals may mask the true duration of lactational anestrus ; this is often the case in non-human primates. In our laboratory, the crab-eating macaque, Macaca fascicularis, reproduces regularly all year long (Dang 1977a), thus permitting us to compare the time-course before the return of postpartum menstruation and fertility with the term of nursing. 


\section{Material and methods.}

Twenty-eight healthy females were used in this study; the rearing conditions have been described elsewhere (Dang, 1977a). We observed 33 birth spaced throughout the year. Thirty of the females were fertilized at the laboratory, and 3 females from Indonesia were already pregnant when they arrived in our colony. All the gestations terminated in the birth of live young. The females were then divided into 2 lots, as shown in figure 1.

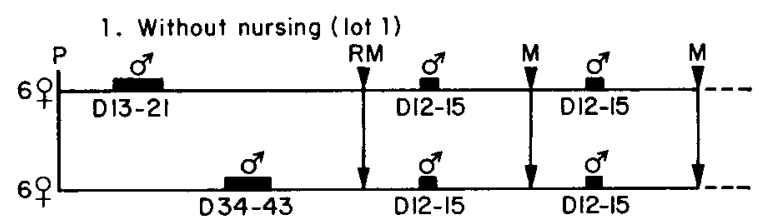

2. With nursing (lat 2 )

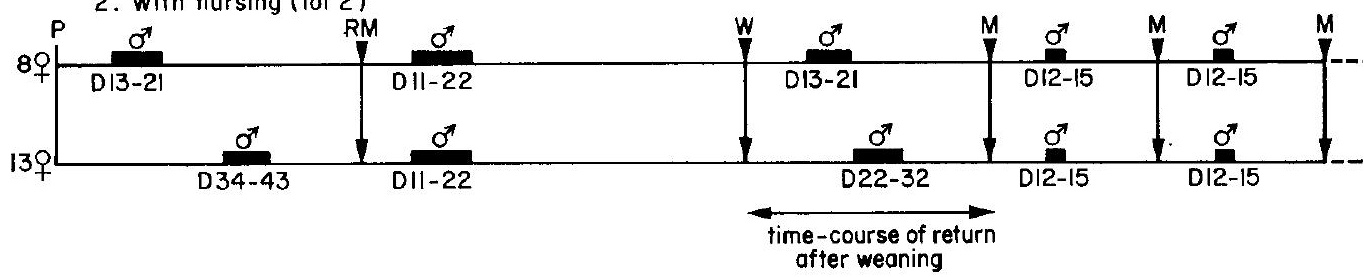

FIG. 1. - Schedule for return of females to males ofter parturition. $D=$ days $; P=$ parturition $; R M=$ return of menstruation ; $M=$ onset of menstruation ; $W=$ day of weaning.

Lot 1 included 12 females which did not nurse ; the newborns were separated from their mothers and artificially fed with a bottle from day 1 or 2 after birth. Six of the females were put with the males again from postpartum day 13 to 21 (during a normal menstrual cycle ovulation generally occurs between days 12 and 14); the other 6 females were put back with the males between postpartum days 34 and 43 . As soon as the 12 females began to menstruate, they were allowed to stay with the males for 24 or 48 hrs starting on day 12 of the menstrual cycle; this is the usual practice in our laboratory.

The nursing females (lot 2) were put back with the males according to the same schedule as lot 1 females. No lot 2 females were receptive to the males during these periods. After abrupt weaning, they were returned to the males (fig. 1) either from post-weaning days 13 to 21 ( 8 animals of first sub-group) or from post-weaning days 22 to 32 (13 animals of second sub-group). After the first post-weaning menstruation, they were put with the males during the usual period in our laboratory (days 12 to 15 of the menstrual cycle).

The animals were examined for signs of menstruation by vaginal smear 6 days per week beginning at postpartum day 10 . Postpartum fertility was determined by pregnancy, confirmed after cesarian or by natural birth. 


\section{Results.}

Lof 1 : Non-lactating females (table 1). - The 12 non-nursing females started to menstruate after a mean delay of $61.7 \pm 7.3$ days. This time-course was the same whether birth took place in March-April or in September-October. None of the 12 females became pregnant before menstruation reappeared, although regular copulation with ejaculation was observed. During the first 6 postpartum menstrual cycles, 10 of the 12 non-lactating females became pregnant. The fertility rate seems slightly lower during the first 2 menstrual cycles, while after cesarian this rate immediately reaches that of the mean of the colony (tables 1 and 3). However, the cycles were few in number, and did not permit a reasonable statistical analysis.

TABLE 1

Return of postpartum menstruation and fertility in non-nursing mothers

\begin{tabular}{|c|c|c|c|c|c|c|c|}
\hline \multirow{2}{*}{$\begin{array}{l}\text { Month of } \\
\text { parturition }\end{array}$} & \multirow{2}{*}{$\begin{array}{l}\text { Time-course } \\
\text { of return }\end{array}$} & \multicolumn{6}{|c|}{ Duration of the following menstrual cycles } \\
\hline & & 1st cycle & 2nd cycle & 3 d cycle & 4th cycle & 5th cycle & 6th cycle \\
\hline $\begin{array}{l}\text { Mar. } \\
\text { id } \\
\text { id } \\
\text { Apr. } \\
\text { Sept. } \\
\text { id } \\
\text { id } \\
\text { id } \\
\text { id } \\
\text { Oct. } \\
\text { id } \\
\text { id }\end{array}$ & $\begin{array}{l}53 d \\
59 \\
66 \\
59 \\
45 \\
55 \\
62 \\
91 \\
53 \\
67 \\
67 \\
64\end{array}$ & $\begin{array}{c}36 d \\
\text { Pregnant } \\
38 \\
34 \\
29 \\
\text { Pregnant } \\
33 \\
28 \\
33 \\
42 \\
36 \\
47\end{array}$ & $\begin{array}{c}36 d \\
36 \\
\text { Pregnant } \\
28 \\
44 \\
51 \\
46 \\
31 \\
39 \\
25\end{array}$ & $\begin{array}{c}\text { Pregnant } \\
35 \\
38 \\
40 \\
\text { Pregnant } \\
28 \\
32 \\
34 \\
\text { Pregnant }\end{array}$ & $\begin{array}{c}37 \\
27 \\
38 \\
\text { Pregnant } \\
31 \\
31\end{array}$ & $\begin{array}{c}36 \\
24 \\
\text { Pregnant } \\
29 \\
\text { Pregnant }\end{array}$ & $\begin{array}{c}\text { Pregnant } \\
27\end{array}$ \\
\hline $\bar{X} \pm S D$ & $61,7 \pm 7,3$ & $35,6 \pm 4,1$ & $37,3 \pm 6,6$ & $34,5 \pm 4,5$ & $32,8 \pm 5,7$ & & \\
\hline Fertility & $0 / 12$ & $2 / 12$ & $1 / 10$ & $3 / 9$ & $1 / 6$ & $2 / 5$ & $1 / 3$ \\
\hline \multicolumn{2}{|c|}{ Fertility } & \multicolumn{2}{|c|}{$3 / 22$ Cycles } & \multicolumn{4}{|c|}{ 7/23 Cycles } \\
\hline
\end{tabular}

Lot 2 : Nursing females (tables 2, 3, 4). - The females refusing to mate during lactation, only one copulation without ejaculation was observed. As regards postweaning fertility in females which had nursed, we distinguished 2 cases :

A. - Females menstruating during nursing. Fifteen of the 21 nursing mothers $(70 \mathrm{p}$. 100) menstruated again after a mean delay of $50.9 \pm 8.3$ days following birth (table 2 ). This delay is not significantly different from that of the females which did not nurse ; if is confirmed by observations on 4 females during 2 or 3 successive pregnancies followed or not by nursing (table 3). The length of the first menstrual cycle during lactation is very irregular (table 2). After weaning, the duration of the menstrual cycles rapidly returned to normal. 
From post-weaning day 13, all females copulated actively and ejaculation was regularly noted every day. However, during this period lasting from weaning to the return of menstruation, only 2 out of 15 females became pregnant. This fertility rate (13 p. 100) appears lower than that of the following 2 cycles $(7 / 21$ or 33 p. 100$)$, which is about the same as the rate in our colony (69/196 or 35 p. 100) for cycling females living with males in the same conditions (Dang, 1977a).

TABLE 2

Refurn of postpartum menstruation and fertility in nursing mothers which menstruated during lactation

\begin{tabular}{|c|c|c|c|c|c|c|c|c|c|}
\hline \multirow{2}{*}{$\begin{array}{l}\text { Month of } \\
\text { parturition }\end{array}$} & \multirow{2}{*}{$\begin{array}{l}\text { Dura- } \\
\text { tion of } \\
\text { nursing }\end{array}$} & \multirow{2}{*}{$\begin{array}{l}\text { Time-course } \\
\text { of postpar- } \\
\text { tum return }\end{array}$} & \multirow{2}{*}{$\begin{array}{l}\text { Duration } \\
\text { of cycle } \\
\text { during } \\
\text { nursing }\end{array}$} & \multirow{2}{*}{$\begin{array}{l}\text { Time-course } \\
\text { of return } \\
\text { after wean- } \\
\text { ing }\end{array}$} & \multicolumn{5}{|c|}{$\begin{array}{l}\text { Duration of the following } \\
\text { menstrual cycles }\end{array}$} \\
\hline & & & & & 1st & 2nd & 3rd & 4 th & 5th \\
\hline $\begin{array}{l}\text { Mar. * } \\
\text { id } \\
\text { id } \\
\text { Apr. } \\
\text { May } \\
\text { Jul. } \\
\text { id } \\
\text { Aug. } \\
\text { Nov. } \\
\text { id } \\
\text { id } \\
\text { id } \\
\text { Dec. } \\
\text { id } \\
\text { id }\end{array}$ & $\begin{array}{c}94 d \\
115 \\
89 \\
127 \\
78 \\
69 \\
67 \\
52 \\
89 \\
74 \\
74 \\
74 \\
80 \\
84 \\
94\end{array}$ & $\begin{array}{l}82 d \\
35 \\
25 \\
42 \\
60 \\
49 \\
49 \\
41 \\
41 \\
36 \\
55 \\
55 \\
72 \\
59 \\
62\end{array}$ & $\begin{array}{l}\overline{70} \\
51 \\
50 \\
= \\
= \\
\overline{-} \\
28 \\
\overline{-} \\
\overline{-} \\
\overline{26} \\
23\end{array}$ & $\begin{array}{c}\text { Pregnant } \\
49 \mathrm{~d} \\
44 \\
41 \\
95 \\
\text { Pregnant } \\
39 \\
51 \\
44 \\
40 \\
59 \\
46 \\
44 \\
51 \\
21\end{array}$ & \begin{tabular}{|c}
$34 d$ \\
Pregn. \\
36 \\
48 \\
\\
27 \\
Pregn. \\
Pregn. \\
63 \\
36 \\
35 \\
Pregn. \\
Pregn. \\
60
\end{tabular} & \begin{tabular}{|c}
$36 \mathrm{~d}$ \\
38 \\
32 \\
23 \\
\\
33 \\
Pregn. \\
36 \\
\\
Pregn.
\end{tabular} & \begin{tabular}{|l}
$36 d$ \\
27 \\
35 \\
Pregn. \\
Pregn.
\end{tabular} & $\begin{array}{c}36 \mathrm{~d} \\
\text { Pregn. } \\
29\end{array}$ & Pregn. \\
\hline$X \pm S D$ & $\begin{array}{c}84,0 \\
\pm \\
10,4\end{array}$ & $\begin{array}{l}50,9 \\
\pm \\
8,3\end{array}$ & $\begin{array}{c}41,3 \\
\pm \\
19,6\end{array}$ & $\begin{array}{c}48,0 \\
\pm \\
10,1\end{array}$ & $\begin{array}{c}42,4 \\
\pm \\
10,9\end{array}$ & $\begin{array}{c}33,0 \\
+ \\
5,6\end{array}$ & & & \\
\hline \multicolumn{2}{|c|}{ Fertility } & $\begin{array}{l}0 / 15 \\
\text { Cycles }\end{array}$ & $\begin{array}{l}0 / 6 \\
\text { Cycles }\end{array}$ & $\begin{array}{c}2 / 15 \\
\text { Cycles }\end{array}$ & $\begin{array}{c}5 / 13 \\
\text { Cycles }\end{array}$ & $\begin{array}{c}2 / 8 \\
\text { Cycles }\end{array}$ & $\begin{array}{c}2 / 5 \\
\text { Cycles }\end{array}$ & $\begin{array}{c}1 / 3 \\
\text { Cycles }\end{array}$ & $\begin{array}{c}1 / 1 \\
\text { Cycle }\end{array}$ \\
\hline & & \multicolumn{2}{|c|}{ Ferfility } & & \multicolumn{2}{|c|}{$7 / 21$} & \multicolumn{3}{|c|}{$4 / 9$} \\
\hline
\end{tabular}

* Pregnant Indonesian female.

B. - Females not menstruating during lactation. 30 p. 100 of the nursing females did not menstruate during lactation. Following weaning, they began to menstruate regularly again after a mean of $50.5 \pm 20.8$ days. This time-course is not different from that of the postpartum delay in females menstruating during nursing or from the time-course of non-lactating females. Although the first 6 menstrual cycles after weaning lasted a normal time, the fertility rate during these cycles tends to be lower than in females menstruating during nursing (table 4). 


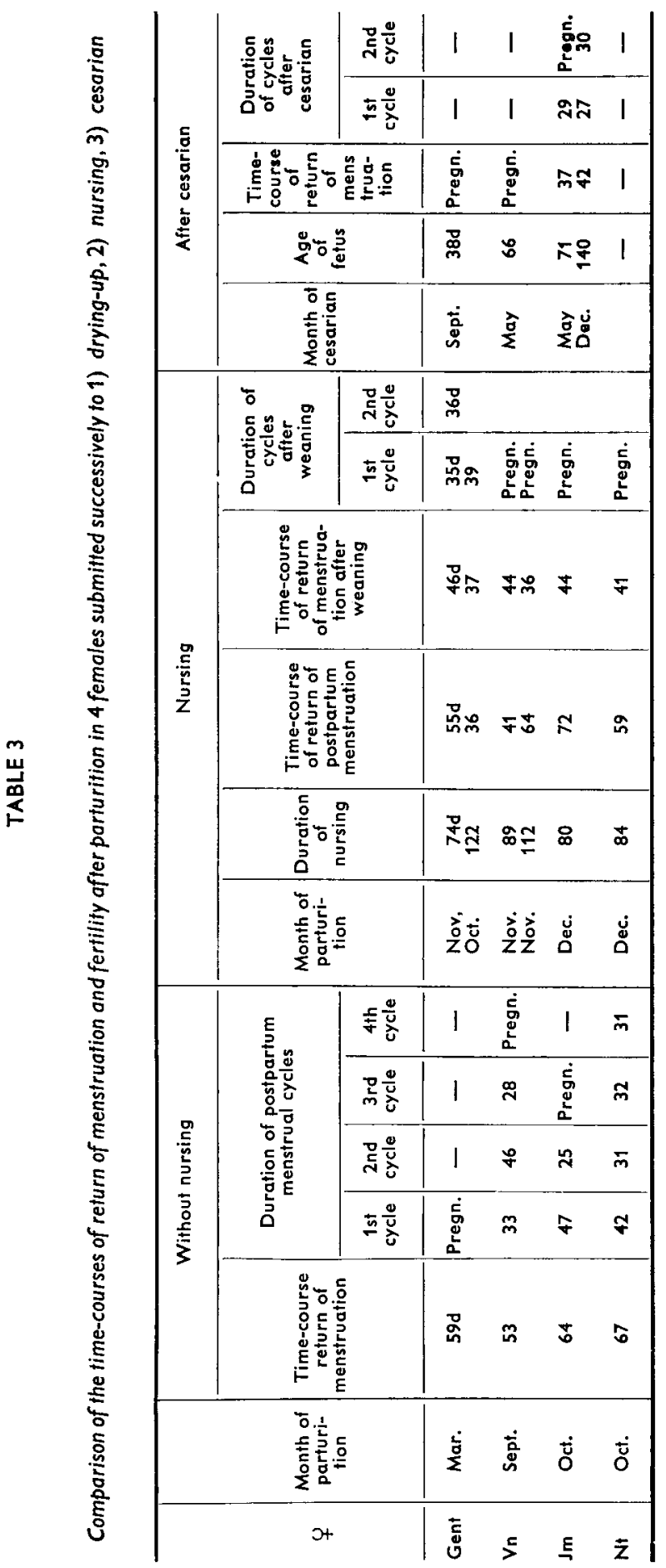


TABLE 4

Refurn of postpartum menstruation and ferfility in nursing mothers which did not menstruate during lactation

\begin{tabular}{|c|c|c|c|c|c|c|c|c|}
\hline \multirow{2}{*}{$\begin{array}{l}\text { Month of } \\
\text { parturition }\end{array}$} & \multirow{2}{*}{$\begin{array}{l}\text { Duration } \\
\text { of nursing }\end{array}$} & \multirow{2}{*}{$\begin{array}{l}\text { Time-course } \\
\text { of post-weaning } \\
\text { return }\end{array}$} & \multicolumn{6}{|c|}{$\begin{array}{c}\text { Duration of the following menstrual } \\
\text { cycles }\end{array}$} \\
\hline & & & $1 s t$ & 2nd & $3 r d$ & 4th & 5 th & $6 \mathrm{th}$ \\
\hline $\begin{array}{l}\text { Jan. * } \\
\text { Feb. } \\
\text { Mar. ** } \\
\text { Nov. } \\
\text { id } \\
\text { id }\end{array}$ & $\begin{array}{l}57 d \\
108 \\
116 \\
75 \\
75 \\
34\end{array}$ & $\begin{array}{l}60 d \\
44 \\
60 \\
76 \\
38 \\
25\end{array}$ & $\begin{array}{l}54 d \\
40 \\
31 \\
28 \\
\dagger \\
+\end{array}$ & $\begin{array}{l}39 d \\
\text { Pregn. } \\
34 \\
26\end{array}$ & $\begin{array}{l}42 d \\
33 \\
46\end{array}$ & $\begin{array}{l}44 d \\
29 \\
\text { Pregn. }\end{array}$ & $\begin{array}{l}35 \mathrm{~d} \\
30\end{array}$ & $\begin{array}{l}39 d \\
31\end{array}$ \\
\hline $\bar{x} \pm S D$ & $77,5 \pm 32,3$ & $50,5 \pm 20,8$ & & & & & & \\
\hline \multirow[t]{2}{*}{ Fertility } & $0 / 6$ & $0 / 6$ & $0 / 4$ & $1 / 4$ & $0 / 3$ & $1 / 3$ & $0 / 2$ & $0 / 2$ \\
\hline & Fertility & & & $\begin{array}{c}1 / 8 \\
\text { Cycles }\end{array}$ & & & $\begin{array}{l}1 / 10 \\
\text { Cycle }\end{array}$ & \\
\hline
\end{tabular}

* Pregnant Indonesian female.

* *Female born in the laboratory.

\section{Discussion.}

Long periods of postpartum amenorrhea have been reported in lactating females ( 60 to 390 days : Spiegel, $1950 ; 29$ to 315 days : Fujiwara et al., 1969) and in nonnursing females ( 2 to 4 months: Goodman and Hodgen, 1978). We observed shorter periods of amenorrhea in this study, i.e. 25 to 176 days in nursing females and 45 to 91 days in non-lactating animals. Contrary to the conclusions of Fujiwara ef al. (1969), we did not find any differences in the time-courses of amenorrhea in females fertilized in the laboratory and those fertilized in their natural habitat.

The delay in return of postpartum menstruation is not significantly different in non-lactating females ( $61.7 \pm 7.3$ days) and in 15 of the 21 nursing mothers $(50.9 \pm$ 8.3 days) which menstruated during nursing. It is longer than the time-course of the menstrual cycle which is $34.5 \pm 1.3$ days (Dang, 1977a), and significantly longer than that noted after cesarian during the first half of pregnancy $(38.0 \pm 2.6$ days ; Dang, 1977b). During these periods, the females did not become pregnant after copulation with ejaculation, either because the copulation dates were poorly chosen or because ovulation did not occur. On the other hand, gestation has been induced before the first menstruation after weaning or after cesarian (Dang, 1977b). Fertility rate returned to normal immediately after cesarian during the first half of pregnancy. It only rose progressively after parturition, more quickly in non-nursing females and hardly at all in those which had not menstruated during nursing. Goodman and Hodgen (1978) studying the crab-eating macaque after parturition without nursing, showed that FSH surges during the delay before menstruation were not followed by peaks 
of estradiol or of LH, although the evolution of these hormones was immediately normal during the first menstrual cycle.

In the females of our colony, the short duration of postpartum amenorrhea and return of fertility after a maximum of 10 months in most cases, could be explained by the fact that Macaca fascicularis adapts well to captivity and that our feeding conditions are good. The importance of the nutritional factor during nursing on return to cyclic sexual activity has been described in women (Short, 1976).

In our colony, there is no seasonal effect on reproduction since all the animals returned to normal cycles after a relatively short period, no matter what the time of the year birth or nursing occurred. These results confirm previous observations in our colony - a semi-open colony owing to the regular introduction of females from Indonesia - that the duration of menstrual and fertility cycles is not season-dependent (Dang, 1977a).

In our rearing conditions, we have made the behavioral observation that at the beginning of nursing the mothers refuse to copulate in spite of the attempts of the males, who might kill the nursed young. The absence of copulatory behavior in nursing non-human primates has been reported by Thompson (1967) in laboratory Macaca fascicularis and by Hrdy (1974) in Presbytis entellus in its natural habitat. However, in Presbytis, when strange males attacked a group and killed the nursed young, the mothers copulated several days afterwards and gave birth to new young 8 months later (Sugiyama, 1965 ; Yoshiba, 1968 ; Rudran, 1973 ; Hrdy, 1974). The refusal to copulate at the beginning of nursing could be due to several causes, among which hyperprolactinemia might play an important role. In fact, if nursing continues more than 5 months, nursing mothers actively copulate, evens with the young clinging to the abdomen (unpublished personal observation), that is at the time when blood prolactin level would be low. In macaque, blood prolactin, level which is very high during the last week of pregnancy (Walsh et al., 1977), drops rapidly at birth when the mother does not nurse (Goodman and Hodgen, 1978) and progressively if the animal does nurse (Knobil, 1973 ; Weiss et al., 1976 ; Gross ef al., 1977).

Women menstruate again after childbirth within 42 to 168 days; this period is frequently longer when they nurse. The menstrual cycles are irregular during the first part of lactation and the ovulation rate, which is very low before the return to menstruation, then progressively increases; this increment is more rapid in nonnursing than in nursing women (Salber et al., 1966 ; Perez ef al., 1972 ; Vorherr, 1973). Blood prolactin level is high at the end of pregnancy, but quickly decreases in nonnursing women and more slowly in those who nurse (Tyson ef al., 1972 ; Rolland ef al., 1975). After abortion between weeks 8 and 20 of pregnancy, menstruation returns within 28 to 49 days - a shorter time-course than after birth at term - and ovulation frequently occurs 14 to 42 days after the abortion (Vorherr, 1973).

The postpartum reproductive function of Macaca fascicularis females thus follows a pattern similar to that of women.

Reçu en mai 1978

Accepté en octobre 1978.

Acknowledgements. - This work was done with the financial help of the DGRST (contract no. 77-7-0671), the CNRS (L. A. 220) and the CNTAS. We also wish to thank 


\section{G. Kann, J. Martinet and C. Thibault for their criticism and constructive discussion during this study.}

Résumé. L'étude du retour des menstruations et de la fertilité chez 28 femelles Macaca fascicularis, élevées au laboratoire et en bonne santé, après une parturition normale, a révélé trois sifuations :

1) Chez les femelles non allaitantes (tabl. 1). Le retour du cycle menstruel se fait dans un délai de $61,7 \pm 3$ jours, la durée des cycles suivants est immédiatement normale. La fertilité, nulle avant le retour des menstruations se rétablit au taux normal après deux cycles. 2) Chez les femelles allaitantes ayant des menstruations pendant la lactation (tabl. 2). Les cycles menstruels, très irréguliers réapparaissent chez 15/21 animaux dans un délai de $50,9 \pm 8,3$ jours. Après l'arrêt d'allaitement, ils deviennent immédiatement réguliers. Mises en présence des mâles, les mères avec leur petit accroché au ventre refusent de copuler pendant cette durée d'allaitement (34-127 jours). La fertilité, faible avant le retour des menstruations après le sevrage, se rétablit d'emblée au cours des cycles suivants.

3) Chez les femelles présentant une aménorrhée pendant la lactation (tabl. 4). Après l'arrêt d'allaitement, les cycles menstruels réguliers réapparaissent dans un délai de $50,5 \pm 20,8$ jours. La fertilité, nulle avant le retour des menstruations, se rétablit plus lentement que chez les femelles précédentes.

Contrairement au cas de césarienne pratiquée au cours de la première moitié de gestation où la fertilité s'installe d'emblée même avant le retour des menstruations (Dang, 1977 b), après la parturition, elle ne se rétablit que progressivement, plus vite quand il n'y a pas d'allaitement. Dans les conditions de notre élevage, la saison ne joue pas de rôle sur la reproduction des femelles de Macaca fascicularis. Sur le plan de la reproduction, la situation post-partum de ces femelles ressemble à celle de la Femme.

\section{References}

DANG D. C., 1977a. Absence of seasonal variation in the lenghth of the menstrual cycle and fertility of the crab-eating macaque (Macaca fascicularis) raised under natural daylight ratio. Ann. Biol. anim. Bioch. Biophys., 17, 1-7.

DANG D. C., 1977b. Resumption of menstruation and fertility after cesarian in Macoca fascicularis. Ann. Biol. anim. Biochim. Biophys., 17, 325-329.

FUJIWARA T., HONJO J., IMAIZUMI K., IMANICHI T., 1969. The postpartum menstruation of cynomolgus monkeys kept under the laboratory conditions. Jap. J. Med. Sci. Biol., 22, 181-185.

GOODMAN A. L., HODGEN G. D., 1978. Post partum patterns of circulating FSH, LH, Prolactin, estradiol, and progesterone in nonsuckling Cynomolgus monkeys. Steroids, 31, 731-744.

GROSS R. J., SCHILLER H. S., BOWDEN D. M., 1977. Postpartum serum prolactin and cortisol and their relationship with maternal and affective behaviors in the Macaca nemestrina. Gynecol. Invest., 8, 97.

HRDY S. B., 1974. Male-male competition and infanticide among the Langurs (Presbytis entellus) of Abu, Rajasthan. Folia primatol., 22, 19-58.

KNOBIL E., 1973. On the regulation of the primate corpus luteum. Coll. Soc. not. Efud. Steril. Fécond. (Paris), 1-18.

PEREZ A., VELA P., MASNICK G. S., POTTER R. G., 1972. First ovulation after childbirth : the effect of breast-feeding. Am. J. Obsief. Gynecol., 114, 1041-1047.

ROLLAND R., LEQUIN R. M., SCHELLEKENS L. A., DE JONG F. H., 1975. The role of prolactin in the restoration of ovarian function during the early post-partum period in the human female. I : A study during physiological lactation. Clin. Endocrinol, 4, 15-25.

RUDRAN R., 1973. Adult male replacement in one-male troops of purple-faced Langurs (Presbytis senex senex) and its effect on population structure. Folia primatol., 19, 166-192.

SALBER E. J., FEINLEIB M., Mac MAHON B. 1966. The duration of postpartum amenorrhea. Am. J. Epidemiol., 82, 347-358. 
SHORT R. V., 1976. Lactation. The central control of reproduction, 73-81. In Breast-feeding and the mother. Ciba Found. Symp., 45 (new series). Elsevier-Excerpta Med. North Holland, Amsterdam, Oxford, N. Y.

SPIEGEL A., 1950. Weitere beobachtungen und untersuchungen über die fortpflansung bei Javamakaken (Macaca irus). Arch. Gynak., 177, 590-629.

SUGIYAMA Y., 1965. On the social change of Hanuman Langurs (Presbytis entellus) in their natural condition. Primates, 6, 381-418.

THOMPSON N. S., 1967. Primate infanticide : a note and a request for information. Lab. Primate Newslett., 6, 18-19.

TYSON J. E., FRISEN H. G., ANDERSON M. S., 1972. Human lactational and ovarian response to endogenous prolactin release. Science, 177, 897-900.

VORHERR H., 1973. Contraception after abortion and postpartum. Am. J. Obstei Gynecol., 117, 1002-1024.

WALSH S. W., WOLF R. C., MEYER R. K., AUBERT M. L., FRIESEN H. G., 1977. Chorionic gonadotropin, chorionic somatomammotropin and prolactin in the uterine vein and peripheral plasma of pregnant rhesus monkeys. Endocrinology, 100, 851-855.

WEISS G., BUTLER W. R., HOTCHKISS J., DIERSCHKE D. J., KNOBIL E., 1976. Periparturitional serum concentration of prolactin, the gonadotropins and the gonadal hormones in the rhesus monkey. Proc. Soc. exp. Biol. Med., 151, 113-116.

YOSHIBA K., 1968. Local and intertroop variability in ecology and social behavior of common Indian Langurs. In JAY P. C., Primates : studies in adaptation and variability. Holt, Rinehart \& Winston N. Y. 